\title{
Integrating career development learning into the curriculum: Collaboration with the careers service for employability
}

\author{
Ruth Bridgstock ${ }^{1}$, Michelle Grant-Iramu ${ }^{2}$ and Alan McAlpine ${ }^{3}$ \\ r.bridgstock@griffith.edu.au; m.grantiramu@qut.edu.au; a.mcalpine@qut.edu.au \\ Corresponding author: Ruth Bridgstock \\ ${ }_{1}^{1}$ Learning Futures, Griffith University, Queensland, orcid.org/0000-0003-0072-2815 \\ ${ }^{2}$ Creative Industries Faculty, Queensland University of Technology \\ ${ }^{3}$ Student Success Group, Queensland University of Technology, orcid.org/0000-0003-4189-2167
}

\begin{abstract}
Career development learning has a demonstrable positive impact on the graduate employability of higher education learners. This is particularly the case if it is integrated into the curriculum rather than experienced as an add-on or included in finite curriculum elements. However, integration of career development learning into curriculum is a significant and challenging undertaking in course design, and also in facilitation of learning experiences. Academics manage crowded curricula in their disciplinary areas, and many also have external course accreditation requirements to deal with that may not include career development elements. In many institutions there is mixed understanding of what career development learning entails, no clear top-level strategic support, and unprecedented numbers of enrolled students across digital and on-campus provision. This article explores challenges and opportunities in integrating career development learning into curriculum in higher education, and identifies effective strategies for doing so at institutional, school, and program levels. It draws upon case studies comprising more than 30 interviews across nine universities in Australia and internationally, exploring how cross-disciplinary collaboration between career development practitioners, learning and curriculum designers, and academic units can be effective in enacting curricular career development learning at scale. The article suggests strategies for institutional leaders, academics, and careers practitioners in higher education insitutions at different stages in the curricular career development learning journey.
\end{abstract}

Keywords: career development learning, careers services, employability, curriculum, course development, collaborative curriculum development, organisational transformation

\section{Introduction}

This article explores the extent to which, and the ways in which, universities are integrating career development learning (CDL) into curriculum to foster graduate employability. Career development learning is an important way that the graduate employability of learners can be enhanced, but there continues to be significantly diverse practice in CDL for employability in different universities. Some are continuing to pursue co-curricular approaches, and others are increasingly seeking to include CDL in the curriculum of degree programs in different ways. One way that curriculum integration is occurring is through collaborative efforts between academic staff, careers services, and curriculum / learning designers, with the enabling strategic support of senior leadership. There are challenges and complexities associated with both curriculum integration of CDL and collaborative efforts for curriculum renovation. This article documents some of the ways that higher education institutions are navigating these challenges and complexities. 


\section{Career development learning and employability}

Career development learning is the acquisition of capabilities that are useful to the lifelong development and management of one's career, grounded in an ongoing authentic learningbased process that builds knowledge of the world of work and one's self (Bridgstock, 2009). This process develops the learner's ability to make sense of and synthesise this knowledge, and form the basis for effective decision-making relating to career choices, professional development and career building activity (including work acquisition).

A key outcome of CDL is career identity development (Holmes, 2013; Tomlinson, 2017). Identity provides both a frame through which students can interpret their capabilities and previous experiences, and a meaningful way to focus future activity. The student's career identity acts as a 'cognitive compass' (Fugate, Kinicki, \& Ashforth, 2004), supporting their learning and career choices, and helping them to make sense of learning experiences.

Career development learning also strengthens learners' capacity to navigate careers and the world of work, including how to obtain work and how to advance in careers. Career development learning emphasises the development of meta-level capabilities, as the focus is on decision-making and planning. It is involved with the development of processual capabilities, in terms of implementing the decisions that shape one's career (Watts, 2006; Patton \& McMahon, 2014).

With the rise of the self-managed career (as opposed to the 'traditional organisational career' within one organisation) in the context of the global knowledge economy, CDL seems increasingly central to people's capacity to engage in meaningful and productive careers. Automation and machine learning, the gig economy, global competition, and structural changes to labour markets and labour policy have changed the way that careers unfold. It is now accepted that the majority of the working population will experience a multiplicity of employment experiences over their lives. The Foundation for Young Australians predicts that young people of today will have 19 jobs across five industries in their lifetimes (Foundation for Young Australians, 2016); it is also likely that they will experience times of unemployment and underemployment; that they may be self-employed at one or several points; that they will need to continually learn to update their capabilities to remain employable in jobs and industries that are changing rapidly. Some of the job changes will be voluntary, but some will be brought about by organisational restructuring or obsolescence of job roles.

There is evidence that CDL has a positive impact on graduate employability in both short-term employment and lifelong-lifewide senses (see Hooley, Marriott, \& Sampson, 2011). Bridgstock (2011) demonstrated this link empirically in a longitudinal study of creative industries graduates, in terms of both subjective (career satisfaction, rated employability) and objective (income) measures of career outcome. Silverberg, Warner, Fong and Goodwin (2004) found that participation in CDL in vocational education impacted positively on young people's shortand medium- term earnings. Gore, Kadish and Aseltine (2003) studied the effects of CDL among high school students from low socioeconomic backgrounds and found a positive impact on the perceived quality of their job roles, the match between their interests and their roles, and the outlook of their careers two years later.

A number of frameworks and theories for CDL have been developed that can be used educationally, commencing with Watts' $(1977 ; 2006)$ seminal DOTS model (the components of which are self-awareness; opportunity awareness; decision-making; and transition learning). Frameworks for CDL across the lifespan were developed in the United States, Canada and Australia in the 2000s (National Occupational Information Coordinating Committee, 1996; MCEECDYA, 2010; Hache, Redekopp, \& Jarvis, 2000). These frameworks are comprehensive expositions of the competencies required for career development in those countries. Bridgstock (2009) developed a model for higher education proposing how, through metacognitive processes, self-management and career building capabilities are related to the development and use of disciplinary and transferable skills for employability.

Bridgstock, R., Grant-Imaru, M., \& McAlpine, A. (2019). Integrating career development learning into the curriculum: Collaboration with the careers service for employability. Journal of Teaching and Learning for Graduate Employability, 10(1), $56-72$. 


\section{How do universities address students' career development learning?}

Career development learning usually happens naturally (if haphazardly and tacitly) through exposure to the world of work and professional contexts. Until as recently as a decade ago (Bridgstock, 2009), students engaged in much of this learning after they graduated from higher education degree programs and embarked on their first career roles. In some instances, this approach can lead to 'false starts', significant career identity revision, and retraining as they belatedly reassess their initial career decisions. Early access to CDL in degree programs builds student understanding of possible career trajectories and supports the development of realistic identities. As students start to understand where the degree might take them, the relevance of the learning becomes clearer, and engagement with the curriculum is strengthened. Students who are less certain why they are in degree programs are more likely to adopt 'just getting by' approaches where the aim is to pass (Nyström, Dahlgren, \& Dahlgren, 2008).

In the current context of a highly crowded and competitive graduate labour market (Karmel \& Carroll, 2016), and where students are paying significant sums to complete university programs, the traditional approach can no longer stand. Students need to have a reasonable sense of what their professional lives might entail, and the confidence that it has a reasonable fit with their initial interests and aspirations. They also need to know that they will have the foundational capabilities required to add value through their work, and to navigate their careers.

Recognising this, universities have started to engage in strategic approaches to foster CDL among their students. These approaches differ according to the type of university, its organisational structure, student needs and degree program profile, its conceptions of graduate employability, the degree of senior leadership support for CDL and employability, and the policy context in which the institution operates (Farenga \& Quinlan, 2015; O'Leary, 2017; Boden \& Nedeva, 2010).

Farenga and Quinlan (2015) summarise three dominant strategies used by UK universities as 'hands off', 'portfolio', and 'award' (see also Bennett et. al., 2017). In the 'hands off' university with high institutional ranking and historical esteem, employability remains implicit in the learning experiences of students, which focus on the development of disciplinary and transferable skills, with little or no mention of career development. The authors point out that in such a university, students may be more likely to possess the cultural capital, and the institution enough reputational capital, that its graduates have privileged access to the most desirable graduate jobs. The 'portfolio' university offers a range of opportunities to students, such as leadership development, CDL, career mentoring, summer internships, job placements, and volunteering. While some of these could be credit-bearing and embedded in curriculum, most are direct-to-student co-curricular activities. The emphasis is on meeting the career development needs of learners through a 'pick and choose' menu of offerings. Finally, the 'award' university offers a formal employability credential through student participation in a wide range of co-curricular (and in some cases curricular) activity, including CDL, entrepreneurship, internships and community engagement.

None of these approaches is optimal in terms of student engagement. In Farenga and Quinlan's (2015) study, their 'portfolio' university only had 3 percent of students in its leadership program, 7 percent were engaged in CDL, and 1 percent in industry mentoring or an internship. The 'award' case study university had only 9 percent of students enrolled in the employability award. Co-curricular schemes raise questions about equity, as students who must do paid work or have caring responsibilities have less time to devote to learning beyond their degree commitments. Co-curricular schemes are most likely to attract high achieving students with well-developed career capital and time above their core studies. More fundamentally, the implementation of these approaches leads to the question: If employability is now a central aim of university learning, why is CDL still addressed in a piecemeal 'bolt on' to the core curriculum? 


\section{Curricular approaches to career development learning}

Bridgstock and Hearn (2012) propose a whole-of-program model for career development in curriculum. Students commence an iterative process of career identity building from first year, reflecting on their core career interests, abilities and values and applying this emergent career identity in the context of industry knowledge and experience, ideally in authentic industry settings and facilitated by industry professionals. This iterative and reflective process develops the 'self-management' aspects of lifelong career management (Bridgstock, 2009). Students are supported to develop adaptive career identities - that is, identities that are grounded in good information about the world of work along with self-knowledge, and identities that are at the same time flexible enough to adapt over time as needed. The learning includes exploring career opportunities they had not yet considered and refining their ideas about work and careers, they are also encouraged to learn the high-level skills associated with whole-of-career development and to continue the process for themselves in an ongoing way. During this career identity building phase, students consider questions such as: What drew me to this course? What are my core work values and how can the range of career options open to me fit with those values? What skills will I require in my intended career and how will I acquire those? How will I cope with setbacks? What will I do if my career needs or the labour market changes?'

Once this process is underway, students are more likely to engage actively and meaningfully with learning opportunities offered during the remainder of the course, and to drive their own capability acquisition, in line with their personal career goals. Once they have started to develop adaptive career identities, students will also be more likely to find worth in the outward career building and 'employment-getting' aspects of career management education, such as capstone programs (Bridgstock, 2009). Thus, the second half of undergraduate courses should develop industry-specific knowledge and know-how, including how to build industry networks, and how to find and obtain or create work.

Renovating content-and-skills based degree curricula to integrate CDL can be a challenging endeavour. These challenges relate variously to the beliefs and capabilities of teaching staff, student expectations, crowded disciplinary curricula, professional accreditation requirements, curriculum development and approval processes, resourcing, and leadership support. If whole-of-program approaches are not taken, the risk is that some subjects will contain CDL elements, and others will not. Rather than a progression of learning through the program as described by Bridgstock and Hearn (2012), students may miss important learning experiences, or repeat them multiple times. Whole of course redesign opportunities typically happen at times of official review and reaccreditation, every few years. Even then, it can be difficult to develop curricula that build upon one another meaningfully, as academic staff often have segmented responsibilities for course subjects.

University programs have a long history of emphasis on disciplinary knowledge and skills, along with critical capabilities and other transferable skills. Integration of employability learning into curriculum has been met with resistance for as long as employability has been part of higher education discourse (Yorke, 2010), and CDL curriculum integration is no exception to this. Some academic staff, argue that it exemplifies vocationalisation and instrumentalisation of the curriculum. Such arguments are also linked with concerns about 'dumbing down' of programs. Further, students may come into programs expecting to learn disciplinary content only. We suggest that if done properly, CDL actually enhances the development of disciplinary and critical capabilities, as well as metacognitive and self-regulation skills. Rather than 'dumbing down' the curriculum, CDL can turn the degree program into a transformative experience for learners, and can in fact enhance disciplinary learning (Mcllveen, 2012). CDL as a foundation and integrator for disciplinary learning is an important threshold concept for students, academic staff, and university leadership alike (Meyer \& Land, 2006). 
Once the value of CDL in curriculum is accepted by staff and leadership, there remains the question of how, practically, to integrate it into programs. Academic staff are subject matter experts in their disciplinary areas, but most do not have specialist CDL expertise. One productive approach to the integration of CDL into curriculum could be to foster intentional collaboration between academics, careers practitioners, and curriculum / learning designers.

\section{Collaboration with the Careers Service for career development learning}

Historically the delivery of career services in universities has primarily been to assist students with occupational and degree program choices. Dey and Cruzvergara (2014) extend Casella's (1990) description of the evolution of the careers service from that of 'advisor' or 'counsellor' with a reactive positioning and impact on a minority of students (Watts \& Fretwell, 2004), to a more proactive contemporary role in the university that also involves education and relationship brokerage (including with industry), and a far greater footprint. Careers services have traditionally been thought of as stand-alone entities (McKenzie \& Howell, 2005), but could be more productively positioned if practitioners were distributed throughout the university in teaching units, providing career development expertise towards curriculum design and delivery.

In exploring this possibility, a number of constraints should be acknowledged. Careers services in universities tend to employ a very limited number of specialist staff, and those staff tend to be trained in advising or counselling. Those who have experience in educational roles have tended to work with small numbers in workshops and one-on-one interactions. They might also be 'parachuted in' to cover specific career topics inside subjects (e.g., 'how to develop an effective CV' in a capstone course). Shifting to a collaborative and comprehensive approach to CDL will involve professional learning on the part of careers staff as well as academics.

\section{Research methods}

This article documents the findings of a study that explored CDL in universities, through interviews conducted in 2017-2018 with 37 staff across nine universities (seven universities in Australia, one in Canada and one in the United Kingdom). For recruitment, initial contact was made with 10 Careers Services Managers known to the research team through their professional networks, of whom nine responded that they were available and willing to participate. The final sample of seven Australian universities included one Group of Eight university, three Australian Technology Network universities, two Regional Universities, and one Innovative Research University. Ethics approval for this research was obtained from the QUT Human Research Ethics Committee. The interviewees included careers services managers and staff, academic leadership at faculty and university levels, academic staff, and curriculum development specialists. The interviewees were asked questions about approaches to employability and CDL adopted at that university, the position of the careers service and the extent and ways in which collaboration was occurring. From the interviews, we: (i) mapped the range of maturity of practice in CDL in the universities we studied; (ii) documented the specific approaches that universities are taking to foster CDL within and outside curriculum; and (iii) explored the collaborative work that some faculties, central units and careers services are undertaking to integrate CDL into the curriculum. In this article, we use three case studies to exemplify the wide range of policies and practices that exist. The number of interview participants across the case study universities and overall is shown in Table 1. 
Table 1: Participant Types and Numbers Across the Nine Universities Studied

\begin{tabular}{|l|c|c|c|c|}
\hline & $\begin{array}{c}\text { Careers services } \\
\text { managers and } \\
\text { staff }\end{array}$ & $\begin{array}{c}\text { Academic } \\
\text { leadership- } \\
\text { faculty and } \\
\text { university }\end{array}$ & Academic staff & $\begin{array}{c}\text { Curriculum } \\
\text { development } \\
\text { specialists }\end{array}$ \\
\hline $\begin{array}{l}\text { All universities } \\
\text { studied (n=37) }\end{array}$ & 11 & 12 & 9 & 6 \\
\hline $\begin{array}{l}\text { Case university 1: } \\
\text { Azure (n=5) }\end{array}$ & 1 & 1 & 2 & 1 \\
\hline $\begin{array}{l}\text { Case university 2: } \\
\text { Argent (n=4) }\end{array}$ & 1 & 1 & 2 & 0 \\
\hline $\begin{array}{l}\text { Case university 3: } \\
\text { Reflex }(n=5)\end{array}$ & 1 & 3 & 1 & 0 \\
\hline
\end{tabular}

\section{Findings}

\section{Integration of career development learning: A range of maturity of practice}

The nine participant universities exhibited a wide range of policy and practice approaches to CDL. There was diversity across curriculum embedded CDL and co-curricular offerings, the positioning of the careers service organisationally and functionally, and the ways in which collaboration between careers services and academic units was happening. The research team synthesised the interview findings at a high level to map the field of maturity of practice among participant universities (Figure 1). Of the nine universities, three were broadly able to be characterised as taking a 'curricular-whole of course' approach, three were taking a mostly 'curricular-subject level' approach, and three were characterised predominantly as 'extracurricular-co-curricular'.

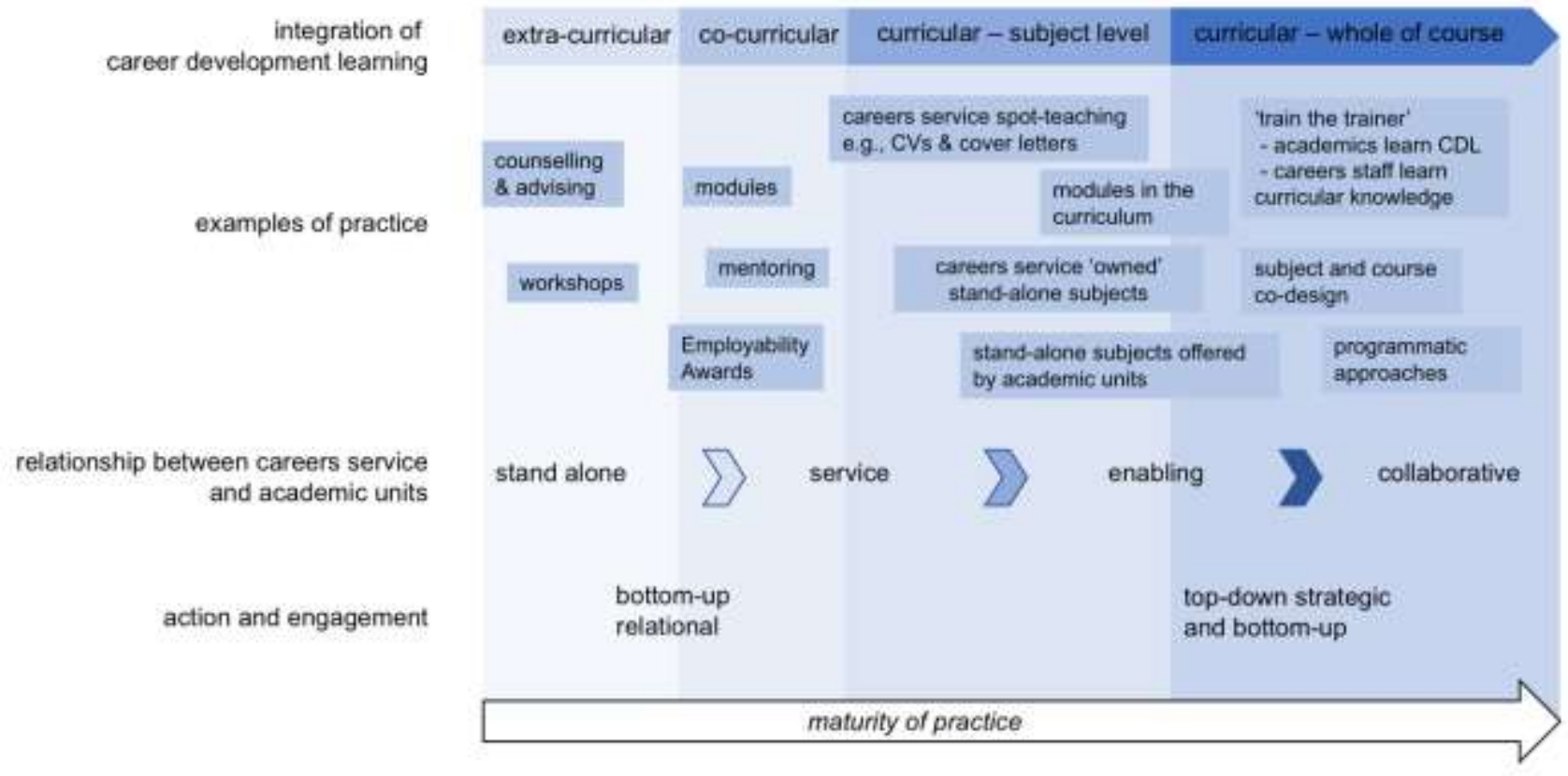

Figure 1: Integration of Career Development Learning into Curriculum: Mapping Maturity of Practice 
The extent of CDL curriculum integration among the participant universities ranged from an 'extra-curricular' pattern, typified by opt-in offerings with no connection to curriculum, through to 'curricular-whole of course' approaches, where CDL is a central underpinning of whole-ofdegree design and review, along with wider elements of the student experience. In between 'extra-curricular' and 'curricular-whole of course', there are universities that are adopting mostly 'co-curricular' approaches, with some links to degree programs. There are also 'curricular-subject' universities, where CDL can be found in some individual units or subjects but is not yet integrated throughout courses or programs.

Each stage of maturity is typified by certain CDL practices. At the extra-curricular stage, optin one-on-one counselling, online modules, industry mentoring, workshops and CV/ cover letter development support are offered to students. At the co-curricular level, this provision may be promoted through courses and programs, and may be recognised through an Employability Award. At the early 'curricular-subject' stage, modules and workshops from earlier stages may be incorporated into teaching and learning resources. Careers staff may be asked to 'spot teach' directly into the curriculum. At later stages of maturity, CDL starts to become integrated into the fabric of the curriculum through intentional design processes, and we start to find career identity development constructs in learning outcomes and activities, often infused with disciplinary learning opportunities. Interviewees spoke about the advantages of curriculum integration for students over co-curricular and stand-alone approaches:

Students live in faculties and courses live in faculties, so much of what we can do in terms of impacting students' experiences is in faculties... It puts a value on it, both for students and for academics. It's in a unit. It's credit. There's assessment connected to some of the learning that's done (115, curriculum designer).

The advantages of whole-of course approaches over individual subject approaches were noted by several interviewees. They acknowledged that a whole-of-course approach is often significantly more challenging to design and deploy and involves considered co-ordination between the academics responsible for individual courses. However, they noted that a wholeof course approach means that CDL can provide links to disciplinary learning and a seamless progression to that learning rather than risking redundancy or gaps in provision:

If I'm a first-year unit coordinator in science, what I might do can be relevant and not risk being the same thing that the person in the unit before just did because they didn't know what I was going to do. And what a third-year unit coordinator might do is built intentionally as part of that framework and can be connected into what that unit is focused on rather than either being the one unit you do somewhere that's all about career development (I27, learning and teaching leadership).

A key challenge to the integration of CDL is the perception that it is 'yet another thing' to add to the curriculum, and that if it is prioritised, important disciplinary learning might be compromised or lost. Interviewees discussed the need to address and allay these concerns openly, using examples of successful practice where necessary:

Not being afraid to challenge notions of the crowded curriculum, to say, the benefits of this work are not counterproductive with what you're trying to do. They completely support it. They align with it. They will make it better. It's not about taking something really important out to put this in. It's about strengthening what you already have by bringing this into the equation as well (I16, employability manager).

In all of the universities studied where CDL had shifted from extra-curricular to more mature, integrated provision, the careers service had played one or several important leadership roles. In the maturity map, the overall positioning and dominant role of the careers service moves from stand-alone and separate from academic units (often located in marketing or student administration organisational areas); to providing a service to academic units; to enabling and

Bridgstock, R., Grant-Imaru, M., \& McAlpine, A. (2019). Integrating career development learning into the curriculum: Collaboration with the careers service for employability. Journal of Teaching and Learning for Graduate Employability, 10(1), $56-72$. 
collaborative roles in teaching, often co-located with academic units. Some careers services managers commented about radical shifts in their roles and organisational positioning, to suddenly finding themselves at the table with university leaders of learning and teaching, developing institutional strategy and policy for graduate employability.

\section{A critical turning point: Top-level strategic vision and enabling support}

While a wide range of maturity was found across the universities, they could be divided into two groups - one group where top-level leadership support for CDL integration was evident, through university employability strategies and strategic learning and teaching plans, and another group where this had not yet occurred. Universities with top-level leadership support moved quickly into 'curricular-course level' and 'curricular-whole of course' stages:

Leadership engagement is essential because you have to convey it as part of the strategy or it's not going to happen (I21, curriculum designer).

Universities without top-level support stayed at earlier stages, with careers teams promoting their services directly to students and relying on relationships with individual academics to include CDL in curriculum:

So much happens here through relational work but if one of those people leaves then we have to start from scratch, whereas if you want to actually create structural change it sits at the level of course design (I1, careers consultant).

Top-level support seems to be pivotal to CDL integration for a number of reasons: it increases awareness and understanding of CDL and its benefits among staff and students; ties CDL to the strategic direction of the university; builds a sense of urgency around the agenda; and provides both space and resourcing for curriculum integration to occur:

If you haven't got the underpinning infrastructure driven by strategic leadership, you can't even get through the door. It's about how you introduce it and now that employability's on everyone's agenda, academics are seeing it and going, 'What is that, what do we do and who do we talk to?' (I20, curriculum designer).

When the Vice Chancellor is talking about employability and is pushing down performance indicators through his senior leadership team, it builds awareness and makes program managers more open to the conversation (118, learning and teaching leadership).

Advocacy for CDL at university-level learning and teaching committees, as well as Facultylevel decision-making groups, was noted to be critical for the success of integration efforts:

...having those people at the table to have the discussions, if we do embark on a new initiative or project, we will have that person at the table reminding us... it elevates the importance, it also reinforces and reminds us of that aspect of student learning (I14, academic leadership).

\section{Bottom-up pioneers and collaborative efforts}

While top-level leadership can often provide a turning-point to enable CDL integration throughout the university, it needs to be met with bottom-up activity in order to create change. For universities that do not yet have top-level leadership enablement of CDL in curriculum, bottom-up, collaborative efforts can strengthen relationships between careers and academic staff, transferring skills and building confidence for curriculum embedded CDL teaching:

I think we have to make the relationship between faculty and career services strong enough that academics see this as part of the core of what we're doing, not something that's someone else's job or they don't have time for or that they don't have the skills (I27, learning and teaching leadership).

Bridgstock, R., Grant-Imaru, M., \& McAlpine, A. (2019). Integrating career development learning into the curriculum: Collaboration with the careers service for employability. Journal of Teaching and Learning for Graduate Employability, 10(1), $56-72$. 
'Relational' approaches, where individual academics and careers services staff collaborate at a subject or even co-curricular level for CDL, were seen by interviewees as effective ways to innovate and try new things, and also to build up an evidence base to convince other academics of the benefits of CDL:

Having local pioneers on the ground, bringing that emphasis to bear in conversations is a very powerful influencer in terms of what gets included and what gets prioritised (I15, curriculum designer).

...you get the evidence base that you can then present to people who initially wouldn't have been so open to the conversation (I19, learning and teaching leadership).

The timing of these collaborative efforts is important. Course teams can be more open to examining curriculum during program accreditation and review periods, and may have access to resources to assist with collaborative CDL integration efforts:

It wasn't halfway through the review, 'Oh, now let's bring them in' it was: 'Can we meet with them initially?...' By coming in right at the start of the year and having been involved through the whole process, everyone's quite happy to have that conversation on how can embed them in (I24, faculty leadership).

It can also be easier to capitalise upon other existing processes and supports in the university than invent new ones:

The library had introduced a compulsory module several years before [our program] and we were able to piggyback on that process in terms of the design, build and rollout of the platform... there was a blueprint which made the process easier (I3, careers services manager).

\section{Road blocks and making the collaboration work}

Interviewees were conscious that challenges to collaboration for CDL stem from historical ways of working in both the careers service and academic units, as well as the different capability sets of the staff involved. Many careers staff have a counselling or consultancy background and end up learning about pedagogy and teaching through the collaboration. Academics, on the other hand, are used to being subject matter experts in their areas of teaching, and may come into the collaboration time-poor and not feeling at all confident teaching CDL.

While academics have these very lean structures because they're dealing with hundreds of students, the careers service staff weren't used to that... We were learning how to engage career service knowledge for the course, and they were learning how to do batch processing, collective feedback and peer feedback (121, university leadership).

...(academic) staff are feeling like they need to build their capability in this area. They're equally feeling lost and they also feel it's not their job. So that's the double whammy. They don't feel confident. They don't have the skills and they also don't get any incentives, reward or workload for doing it. So, they're your roadblocks (118, learning and teaching leadership).

In universities where CDL integration is well established, scalability can be a challenge, as there may not be enough careers staff to work directly inside programs. Some careers services adopt a 'train the trainer' strategy, which involves careers staff facilitating professional learning of academic staff and being involved in the recruitment of suitable academics to support CDL in the curriculum:

We work with them to say, 'We can support you on this basis in the first year of doing this, but whilst we do, we need to put into place how you're going to sustain this, and whether that's through bringing in teaching fellows or recruiting for an academic lead for this module. This may be about putting together job descriptions, work allocation 
models, to go and pitch at college board meetings to get the buy-in for that' (I16, employability manager).

Interviewees from universities with mature collaborative CDL practice talked about making an effort to work in the same communities and spaces; making the work a shared enterprise and developing a shared language:

Language has been really important in trying to engage our academic community... when you talk about trying to work with them to produce creative thinkers that are action orientated, that are able to take their research to the next level, that are able to create a legacy in their local community, that expands our capacity for knowledge transfer and exchange (I16, employability manager).

\section{A closer examination of three university case studies}

Varying degrees of CDL curriculum integration maturity, and diversity of policy and practices were evident in the universities studied in this project. The following three case studies provide examples of how different universities are engaging with CDL, and how they are navigating opportunities to collaborate for CDL curriculum integration.

\section{Case 1: Azure University}

Azure University is a large Australian metropolitan university, established in the 1980s. Its overall approach to CDL could be described as the early stages of 'whole of course' based in university-wide strategy. The careers service and faculty staff collaborated on the development of CDL curriculum framework two years ago, at a time when the priorities of employability had a renewed strategic emphasis across the university. There was significant structural change to support the framework implementation that brought the careers service out of the student support services area and into the central learning and teaching area:

As structural change occurred, we were able to connect and leverage that and move into a learning and teaching space where we could be more strategic in embedding $C D L$ (I1, careers consultant).

The new structure increased the visibility of careers consultants and shifted their physical location, with career teams now sharing office space with teaching and learning teams and spending more time working with them:

We are changing those roles and taking them out to where we think students are at, and providing greater opportunities for them to connect into curriculum so that they're informing the design of our courses (I27, learning and teaching leadership).

While this approach is in its early stages, it is working to connect careers educators with the university's curriculum designers, learning designers and course teams, as well as anchoring a framework of CDL in the requirements for redesigned and newly designed curricula.

Significant leadership support combined with an extensive consultation process was fundamental to the success of curriculum integration:

Getting traction with enough senior stakeholders at the university has been effective in getting the message across and we're now able to effectively drive course change (I27, learning and teaching leadership).

In addition to leveraging leadership support, engagement with the emergent curriculum framework was enhanced through a university-wide summit, which created a space where academics, professional staff and students could highlight what the university does well and start to identify the possibilities and potential elements of the framework's design. The careers service continued to consult with stakeholders through an advisory group that provided ongoing feedback and tested design components. 
People wanted flexibility, it needed to be able to be used in multiple ways and be contextualised... we've since struggled to keep up with demand because the process has created an appetite for the work by keeping people engaged (I1, careers consultant).

The CDL framework at Azure is supported by resources and modules that curriculum and learning designers can draw on when they are working with course teams and unit coordinators. While online CDL modules had been widely used previously at Azure, people used them for the things that made sense to them around employability and didn't engage with the self-awareness and broader employability concepts (I1, careers consultant). The new structure and approach has enabled curriciulum designers to act as conduits for collaboration:

There is also an opportunity to bring career educators in to speak with course teams directly to develop and skill academics up to really bring alive in their classroom the importance of employability and careers skills (I15, curriculum designer).

Different levels of faculty readiness was acknowledged as a key consideration when rolling out the framework across the university:

I don't think I could say that there's a common point at which everybody has arrived. Everybody's probably reached the threshold of acknowledging that those sorts of skills are critical. Probably the divergence is where people see the responsibility for that (I15, curriculum designer).

An awareness of faculty readiness has informed the roll out, with early work focussed on early adopters and champions of the framework. Faculty teams that have been engaged in the process see their role as being flagship units that can convey the benefits of the process as well as highlighting emergent issues and processes for alleviating difficulties.

Resourcing remains a challenge for both faculty and the careers service, and highlights questions of sustainability for collaborative course development and delivery:

We're still working our way through what that will look like going forward. In terms of how it's worked over the past six months, it's been a bit of good will, to be honest (I17, academic staff).

The next step involves incremental levels of evaluation:

The first is actually tracking usage and understanding how people are using it and capturing additional specialised development. The second is user experience: Do people like it? Have they learned anything from it?... The next level is behaviour change: once this has been in place, do we see a change in the way people engage with this? (I1, careers consultant).

\section{Case 2: Argent University}

Argent University is a reasonably large university originally established in the 1960s, with campuses in metropolitan, suburban and regional locations in Australia. Its overall approach to CDL for graduate employability is co-curricular, with some moves into curricular-subject level integration. The university has recently launched an enterprise-wide co-curricular employability program based on career and employability capabilities, the framework for which was co-developed with employers. Strategies are also being developed and piloted to shift elements of the program into the curriculum.

University leadership provided initial momentum in shifting perceptions around the role of the careers service, with acknowledgement that student outcomes are important for the university. As part of a recent university-wide restructure, the careers service was shifted out of the student services area and into the learning and teaching area.

To some extent it was to give that impetus into the curriculum, to raise the importance of employability skills within the curriculum, which was harder to do as a stand-alone service (12, student services leadership). 
Since then, the careers service has been moved back out of the teaching and learning space into student services.

I think we got a little lost there... [but]... it was at that point that we were able to engage others in what employability at our university looked like and what it meant (I12, student services leadership).

The temporarily enhanced visibility of the careers service and the increased focus on employability coincided with a strategic funding initiative... (which brought $C D L$ )... to the forefront. Although the strategic funding aspect of it has gone, (CDL is) still there and it's still developing in different ways (I 12, student services leadership). The careers service manager now sits on a working party with teaching and learning leadership, curriculum development staff, faculty teaching and learning representatives, and some industry partners. The terms of reference incorporate the development of a curricular employability framework:

... hopefully we'll be able to provide some recommendations to the university around an approach to embed employability into the curriculum (14, careers service manager).

Gaining an understanding of 'employability' across the university was also viewed as part of this process.

Language is important. We all need to know that if we say 'employability', this is what we mean, and we need the students to understand that's what we mean as well (I12, student services leadership).

The careers service has already developed a co-curricular CDL program:

...even though it's been designed primarily as a co-curricular program, we've designed it so that it will integrate into the curriculum. We are now starting to get students engaged in that. We can expand that across all courses now (14, careers service manager).

Another prong of the Argent employability strategy is to work with academics to identify where CDL currently exists within courses, and where staff can be supported to integrate it:

...it's a gap analysis that we're in the early stages of undertaking... if we can link [our core capabilities] to what already exists and just identify the gaps we need to fill, we'll have it embedded within subjects and be able to extend that out (I12, student services leadership).

The careers service includes a careers education team that collaborates with academics on a number of pilot projects aimed at integrating CDL into curriculum in customised ways using relational approaches. These pilot collaborations have grown out of the careers service's own personal networks, academics that are very highly engaged with their students, have a high level of concern around employability and have seen the need to do something (I 4, careers service manager). One pilot involves a collaborative redesign of an undergraduate course curriculum, embedding CDL from the outset of the course, and then in core second and third year subjects:

I'm very interested in using [the careers team's] professional skills and shaping our curriculum in ways that are more relevant for employability (I22, academic staff).

An identified challenge relates to the role of the careers team in course delivery:

...there's some debate in the senior academic leadership over where the lines are drawn between the careers staff being involved in face-to-face delivery. One line that we've never crossed is having them directly involved in assessment (I22, academic staff).

It was also acknowledged that academic readiness varies, and this means that strategies for expanding faculty engagement also need to vary:

It takes a lot of conversations and time to get to know each discipline to be able to see where those opportunities might be... It's still an open question as to what that approach 
will be, and these pilots will be able to inform some of that thinking (14, careers service manager).

A further challenge relates to the changing demands on careers staff and the new skill sets required for collaboration, curriculum influence and student engagement within academic spaces.

Trying to assist [careers staff] in appropriate professional development... If they're not across your [disciplinary] subject area, academics are less likely to be wanting to engage and less likely to want to change what they're already doing (I12, student services leadership).

Next steps for Argent include the expansion of curriculum initiatives, and ongoing strategy development to influence cultural change.

\section{Case 3: Reflex University}

Reflex University is a reasonably large Australian metropolitan university established in the 1990s, with multiple campuses across metropolitan, suburban and regional locations, and an emphasis on online learning. One faculty of the university has adopted a whole-of course approach to CDL, and other faculties operate at different levels of maturity of integration.

Working from within the university's student services area, the careers service has developed an employability model that includes incremental principles for scaffolding CDL across whole of course delivery. The model is operationalised into a series of online modules that are in development.

The aim is that all of these modules will be developed and available online for all students to undertake (I5, careers service manager).

The careers service has also been working to gain traction in the curriculum among faculty leadership and through early faculty adopters.

'Influencing up' and engaging champions using a relational approach has been important to success at Reflex. For example, supportive leadership in student services championed the model with leadership in a faculty area. The faculty Dean then invited the careers service to present at a teaching and learning committee meeting. Faculty leadership buy-in has underscored the progress of integrating the CDL model:

...because in a university with strategic priorities, if your priority isn't as important as other priorities they can say, 'we need to spend more money on research, not CDL'(I13, student services leadership).

The combination of timing and increased visibility among faculty leadership led to the initiation of a Faculty-based pilot collaboration with the careers service. The pilot informed and resourced the development of the first three online modules, and also helped to refine the model and identify connection points across their curriculum:

We looked at their CDL map and help them simplify it... We started with career learning in first year as a conscious strategy to build students' career differentiation before they move into internships and international experiences (121 faculty leadership).

A careers consultant was seconded as a course co-ordinator into faculty and worked to design and co-deliver the first three modules in curriculum. This not only progressed the actualisation of the careers service model, but also built expertise among collaborators.

From a faculty leadership perspective, it was acknowledged that while leadership was important in initiating collaboration, it was equally important to create an environment where academics could take ownership of these ideas: 
I took a back step, initiated the introductions and then stepped away and said, 'I'm here if you need me but you run with it, you're the experts within this program' (I24, faculty leadership).

While the piloting faculty emphasised that the modules were generic and could be embedded into any university course, they also suggested that tutorial staff have relevant expertise:

It can't be just a lump that sits there. You have to unpack it and have qualified staff to engage with it (121, faculty leadership).

Engaging part-time career advisors as course tutors also assisted in linking what was being taught with the other services offered by the careers team:

We made sure that as many as possible of our tutors were from that background because we wanted that to be a shop front to what the careers service does as part of the student experience in the first year (I21, faculty leadership).

Collaborating with early adopters has worked to build an evidence base and secured champions for the model:

I think you have to be quite pragmatic and you work with those who are on the same page as you at that moment in time. You influence those that you can influence and then you get the evidence base so you can then present to people who initially wouldn't have been so open to the conversation (I13, student services leadership).

The pilot enabled leadership from the collaborating faculty to present evidence to the senior management committee and to facilitate conversations with other faculty leaders:

I wanted to help show what the careers service could do ... and I wanted my colleagues at senior management group to think differently about career and professional development (I21, faculty leadership).

Student services leadership in the university supports the careers team to identify potential partners and target their collaborative endeavours. The emergence of a new faculty-based collaboration highlights the value of increase awareness and leadership advocacy:

We undergo a five-year review of our programs, and [one program] was up for review, which had some issues that we needed to address... So, I touched base with [the careers service] (I24, faculty leadership).

One of the challenges of Reflex's model delivery is resourcing:

The key role I have is to make sure it is resourced effectively so that we don't have staff having to absorb additional work over and above the day job that they're already currently doing (I19 student services leadership).

The other key challenge is the claim that there's no room in the curriculum:

That's a mindset challenge from a lot of academic staff, and we'll just keep chipping away at it... where we'll have leverage is we'll have a suite of evidence that demonstrates the benefit of actually taking the approach (I19 student services leadership..

The next steps for Reflex are to develop the modules for the second and third phases of the CDL model, and to continue leveraging the success of existing collaborations to broaden faculty engagement.

\section{Conclusion: Ways forward for curricular integration of career development learning}

The three case studies discussed in this article show the different approaches that universities are taking to CDL in curriculum. At Azure, development of top-level enabling strategy, a 
university-wide CDL framework and structural organisational changes have facilitated collaborative curriculum development. At Argent, co-curricular approaches and bottom-up subject-level collaborations are supporting moves towards whole-of-course level integration. At Reflex, a pilot collaboration between one Faculty and the careers service is paving the way for wider systemic change.

The university careers service can be an important source of collaborative expertise for integration of CDL into curriculum, but the process of integration remains a complex one, often involving organisational, policy and culture changes, and requiring identity shifts and capability development among the staff involved. This study has shown, in line with wider studies of transformative change in universities (e.g., Kezar \& Eckel, 2002) that both top-down and bottom-up processes need to happen concurrently for a truly institution-wide, integrated approach. Bottom-up collaborative work between academic staff, careers staff, and curriculum / learning designers to design and deliver CDL-infused curriculum can be enormously fruitful, but requires the right kinds of relational and engagement processes, and often entails significant professional learning for all involved. Top-down strategic enabling approaches are crucial to enacting institutional change, through policy, organisational structure, and resourcing pathways. For senior leadership to champion CDL, they require evidence of its efficacy and a clear understanding of what it entails. Evidence of efficacy can be drawn from the academic literature, and from rigorous evaluative studies of career development learning practice that demonstrates changes in student capability and behaviour.

Career development learning is about much more than CVs and cover letters. It is about the progressive formation and refinement of identity through learning, along with the development of a set of meta-level capabilities to do with sense-making of learning experiences, informed decision-making and planning of life and career (Watts, 2006; Bridgstock, 2009). It therefore makes sense for CDL to be integrated with higher education curricula. In so doing, all students can receive the benefits to learning and employability that CDL confers. 


\section{References}

Bennett, D., Knight, E. B., Divan, A., Kuchel, L., Horn, J., van Reyk, D., \& Burke da Silva, K. (2017). How do research-intensive universities portray employability strategies? A review of their websites. Australian Journal of Career Development, 26(2), 52-61.

Boden, R., \& Nedeva, M. (2010). Employing discourse: Universities and graduate "Employability". Journal of Education Policy, 25(1), 37-54.

Bridgstock, R. (2009). The graduate attributes we've overlooked: Enhancing graduate employability through career management skills. Higher Education Research \& Development, 28(1), 31-44.

Bridgstock, R. (2011). Skills for Creative Industries graduate success. Education \& Training, Vol. 53(1), 9-26.

Bridgstock, R., \& Hearn, G. (2012). A conceptual model of capability learning for the 21st century knowledge economy. In D. Rooney, G. Hearn, \& A. Ninan (Eds.), Handbook on the knowledge economy (pp.105-122). Cheltenham: Edward Elgar.

Casella, D. A. (1990). Career networking-The newest career center paradigm. Journal of Career Planning \& Employment, 45(3), 33-39.

Dey, F., \& Cruzvergara, C. Y. (2014). Evolution of career services in higher education. New Directions for Student Services, 148, 5-18.

Farenga, S., \& Quinlan, K.(2016). Classifying university employability strategies: Three case studies and implications for practice and research, Journal of Education and Work, 29(7), 767-787.

Foundation for Young Australians. (2016). The New Work Smarts: Ensuring young Australians have skills and experience for the jobs of the future, not the past. Retrieved from https://www.fya.org.au/report/the-new-work-smarts/

Fugate, M., Kinicki, A. J., \& Ashforth, B. E. (2004). Employability: A psycho-social construct, its dimensions, and applications. Journal of Vocational Behavior, 65(1), 14-38.

Gore, S., Kadish, S., \& Aseltine Jr, R. H. (2003). Career centered high school education and post-high school career adaptation. American Journal of Community Psychology, 32(1-2), 77-88.

Hache, L., Redekopp, D., \& Jarvis, P. (2000). Blueprint for life/work designs. Retrieved from http://www.blueprint4life.ca

Holmes, L. (2013). Competing perspectives on graduate employability: Possession, position or process? Studies in Higher Education, 38(4), 538-554.

Hooley, T., Marriott, J., \& Sampson, J. P. (2011). Fostering college and career readiness: How career development activities in schools impact on graduation rates and students' life success. Derby: International Centre for Guidance Studies, University of Derby.

Karmel, T., \& Carroll, D. (2016). Had the graduate job market been swamped? NILS working paper series No.228/2016. Adelaide: National Institute for Labour Studies.

Kezar, A., \& Eckel, P. (2002). Examining the institutional transformation process: The importance of sensemaking, interrelated strategies, and balance. Research in Higher Education, 43(3), 295-328.

MCEECDYA. (2010). Australian Blueprint for Career Development. Ministerial Council for Education, Early Childhood Development and Youth Affairs, Canberra, Australian Capital Territory.

Mcllveen, P. (2012). Transformative career development learning: Building capacity for selfdetermination. In P. A. Danaher, L. De George-Walker, R. Henderson, K. J. Matthews, W. Midgley, K. Noble, M. A. Tyler \& C. H. Arden (Eds.), Constructing capacities: Building capabilities through learning and engagement (pp.144-159). Newcastle Upon Tyne, United Kingdom: Cambridge Scholars Publishing,

McKenzie, M., \& Howell, J. (2005). A snapshot of Australian university career services. Australian Journal of Career Development, 14(2), 6-14.

Meyer, J., \& Land, R. (2006). Overcoming barriers to student understanding: Threshold concepts and troublesome knowledge. Routledge.

NOICC. (2007). National Career Development Guidelines. Washington, DC: National Occupational Information Co-ordinating Committee 
Nyström, S., Dahlgren, M., \& Dahlgren, L. (2008). A winding road-professional trajectories from higher education to working life: A case study of political science and psychology graduates. Studies in Continuing Education, 30(3), 215-229.

O'Leary, S. (2017). Graduates' experiences of, and attitudes towards, the inclusion of employability-related support in undergraduate degree programmes; trends and variations by subject discipline and gender. Journal of Education and Work, 30(1), 84-105.

Patton, W., \& McMahon, M. (2014). Career development and systems theory: Connecting theory and practice. ( $3^{\text {rd }}$ ed). Rotterdam: Sense Publishers

Silverberg, M., Warner, E., Fong, M., \& Goodwin, D. (2004). National Assessment of Vocational Education. Final Report to Congress. Washington, DC: US Department of Education

Tomlinson, M. (2017). Forms of graduate capital and their relationship to graduate employability. Education+Training, 59(4), 338-352.

Watts, A.G. (1977). Careers education in higher education: principles and practice. British Journal of Guidance and Counselling, 5(2), 167-184

Watts, A. G. (2006). Career development learning and employability. London: Higher Education Academy.

Watts, A. G., \& Fretwell, D. H. (2004). Public policies for career development. Case studies and emerging issues for designing career information and guidance systems in developing and transition economies. Washington DC: World Bank Education Advisory Service.

Yorke, M. (2010). Employability: Aligning the message, the medium and academic values. Journal of Teaching and Learning for Graduate Employability, 1(1), 2-12. 